\title{
ENRICHMENT OF SEDIMENTS IN URBAN RIVERS BY HEAVY METALS
}

\author{
JUCHEN C. $R^{1}$ \\ VILAS BOAS M.A. ${ }^{2}$ \\ POLETO C. ${ }^{3}$ \\ JUCHEN P.T. ${ }^{2, *}$
}

\author{
${ }^{1}$ Department of Chemistry Process \\ Federal Technological University of Paraná, Toledo Brazil \\ ${ }^{2}$ Department of Agricultural Engineering \\ Western Paraná State University, Cascavel, Brazil \\ Hydraulic Research Institute \\ ${ }^{3}$ Federal University of Rio Grande do Sul, Porto Alegre, Brazil
}

Received: $14 / 04 / 2016$

Accepted: 07/06/2016

Available online: 19/07/2016

\section{ABSTRACT}

The heavy metals contained in sediments may be responsible for constant degradation of rivers' water quality, which circulate in an urban environment. Therefore, this study shows the pollution index and enrichment factor for each of these elements in river sediments. It was used the optical emission spectrometry with inductively coupled plasma (ICP-OES) and total organic carbon (TOC) by dry combustion. The enrichment factor of sediments were normalized by aluminium concentration. From the point of view of toxicology, the elements $\mathrm{Ba}, \mathrm{Cr}, \mathrm{Pb}$ and $\mathrm{Zn}$, and the macro chemical elements $\mathrm{Fe}, \mathrm{Mg}$ and $\mathrm{Na}$ showed to be more significant. When used the references of local background, the enrichment percentages for $\mathrm{Ba}, \mathrm{Cu}, \mathrm{Cr}, \mathrm{Ni}, \mathrm{Zn}, \mathrm{Mg}$ and $\mathrm{Na}$ respectively were $39.3 \%, 44.3 \%, 56.3 \%, 18.6 \%, 140.2 \%$, $18.4 \%$ and $295 \%$. The percentage of TOC did not exceeded the limit of $1 \%$ at any of the points of sampling. According to the main worldwide guidelines, the obtained concentrations for $\mathrm{Cd}, \mathrm{Cr}, \mathrm{Cu}, \mathrm{Ni}$ and $\mathrm{Zn}$ in the majority of the points of sampling, are rates from which can be expected adverse effects in the aquatic environment. This occur due to theirs capacities to release these elements in the flowing. Therefore, this study are relevant scientific data to indicate the water quality of urban rivers.

Keywords: Hydro sedimentology, metals in urban rivers, diffuse pollution

\section{Introduction}

The Brazilian Institute of Geography and Statistics (IBGE) in 2011 indicated that 160 million people, about, $84.35 \%$ of people who live in Brazil inhabited the urban centers. The immediate consequence of this population expansion are anthropic contributions. This promote the enrichment of urban area sediments by heavy metals. Thus, contaminate the aquatic environment by the fact that urban rivers naturally perform the drainage of these areas, being the final destination of these chemical elements.

To understand the process of pollution in urban water bodies is necessary to understand what are the sources of pollutants, their form of transport, deposition, accumulation and release. In this context, the sediments earn big highlight, because they are considered important agents of this process (Cardoso and Poleto, 2012).

In 2012, the European Sediment Research Network (SEDNET) defined sediment. It is a material formed by: solid particles that constitute mineral particles; fragments of rock; carbonates; precipitated compounds of iron, manganese, aluminum and organic compounds in several stages of decomposition. 
In addition, sediment can be associated elements that are carried by geological agents, because they act as the main component of a matrix susceptible to transport through the water.

The heavy metals are inserted into the sediments by anthropogenic means that occur in an urban environment due to commercial and industrial activities. Carried by urban drainage, these flowing sediments can be used as environmental indicators and of monitoring. Because they present important information about the river's degree of pollution, due to the fact that these trace elements may be released at any moment to the water column.

Most heavy metals are also called trace elements, which are defined as those that occur in low concentrations (generally below $0.1 \%$ or $1000 \mathrm{mg} \mathrm{kg}^{-1}$ ) in soil, air, water, plants and animals (Kabata and Pendias, 2007). They are different from organic compounds, because are not easily degraded. One of the ways to check its enrichment in sediments is by values obtained on the background or by Guidelines. Currently, in Brazil, there are no standards of trace elements for sediment, except by National Council of the environment legislation (Brazil, 2012), which regulates the dredging and disposal of dredged material.

Many studies in different countries revealed high concentrations of heavy metals and trace elements in rivers' sediments in the world. Grosbois et al., (2001) already reported that the sediments of Spokane River in US were enriched in $\mathrm{Pb}, \mathrm{Zn}, \mathrm{As}, \mathrm{Cd}, \mathrm{Sb}$, and $\mathrm{Hg}$, in relation to its background. Sediments of Odiel river, in southwest of Spain, due to mining and industrial activities, presented high concentrations of $\mathrm{Zn}$, $\mathrm{Pb}$ and $\mathrm{Cu}$ (Beltrán et al., 2010). The same occurs in the Rivers Ganges, Yamuna, Hindon, Narmada and Kanini in India (Hejabi et al., 2011). Several rivers of China, as the Pearl River, Yangtze, Yellow and Songhua, have their sediments contaminated with high concentrations of trace elements (Wang et al., 2011; Feng et al., 2010).

A study that analyzes just the quality of rivers' water may demonstrate its pollution status. However, checking levels of heavy metals in its flowing sediments, or river bottom sediments can show a situation more real about its potential polluter. Thus, the present work aim to determine in rivers, which receive the full discharge of sediments from the city of Toledo PR, the sediments concentrations of the following heavy metals and trace elements: $\mathrm{As}, \mathrm{B}, \mathrm{Ba}, \mathrm{Cu}, \mathrm{Cd}, \mathrm{Cr}, \mathrm{Mn}, \mathrm{Ni}, \mathrm{Pb}, \mathrm{Sb}, \mathrm{Se}, \mathrm{U}$ and $\mathrm{Zn}$. These elements were analyzed due to their relevance from toxicological point of view. Additionally, it was determined the concentrations of $\mathrm{Al}, \mathrm{Fe}, \mathrm{Mg}, \mathrm{Na}$ and $\mathrm{C}$ for being macro elements involved in geochemical cycles of this geochemical environment.

\section{Materials and Methods}

Figure 1 shows the urban perimeter of Toledo city located in west of Paraná state, in South of Brazil. Geographically, Toledo city has an area of $1,140,751 \mathrm{~km}^{2}, 547$ meters of altitude, latitude of $24^{\circ} 45^{\prime} 50^{\prime \prime}$ South and longitude of $53^{\circ} 44^{\prime} 34^{\prime \prime}$ West. It has a dense hydrographic net, composed of rivers that flow in the east-west direction, which integrate Paraná Bay III.

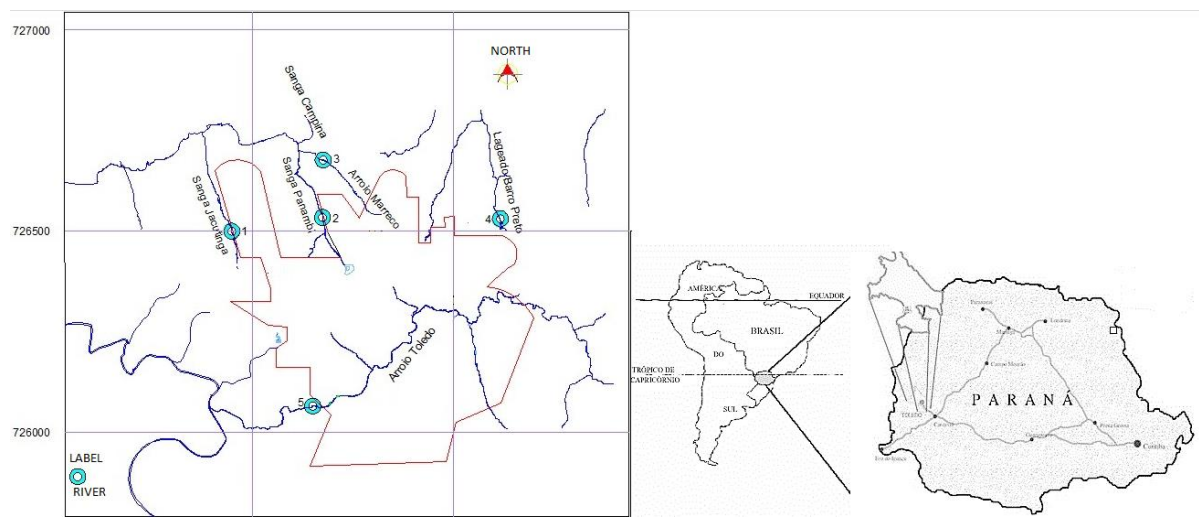

Figure 1. Hydrography of the urban perimeter of Toledo city PR and location of collection points of sediments 
According to the classification of Köppen climate, the climate is humid subtropical Mesothermic, with hot summers (average temperature above $22^{\circ} \mathrm{C}$ ). In addition, it has a tendency toward concentration of rains, winters with some infrequent frosts (average temperature less than $18^{\circ} \mathrm{C}$ ), without defined dry station.

The soil of the region is classified as LVef - eutroferric Red Latosol (EMBRAPA, 2013) with a great fertility, therefore, the city has character essentially agro industrial. Currently, the population is estimated at 120,000 habitants (IBGE, 2011), of which $79.7 \%$ have treated sewage in anaerobic reactors of sludge fluidized - RALFs and the remaining are deposited in septic tanks and sinks.

As shown in Figure 1, it was selected five rivers that have its springs in urban perimeter or travel across it. In this way, they are receivers of almost all of sediments generated by the city and subject to major anthropic influences. Their geographic reference and features are showed in the Table 1 . The collections were carried out monthly from April 2013 to March 2014.

Table 1. Description and geographical location of collection points in the areas of study

\begin{tabular}{ccl}
\hline River & Geographic coordinates & \multicolumn{1}{c}{ Designation/ activities nearby } \\
\hline 1 & $\mathrm{~S} 24^{\circ} 42^{\prime} 10^{\prime \prime}-\mathrm{W} 53^{\circ} 46^{\prime} 40^{\prime \prime}$ & Jacutinga/residence and horticulture \\
2 & $\mathrm{~S} 24^{\circ} 41^{\prime} 54^{\prime \prime}-\mathrm{W} 53^{\circ} 45^{\prime} 23^{\prime \prime}$ & Panambi/fish-farming and horticulture \\
3 & $\mathrm{~S} 24^{\circ} 41^{\prime} 47^{\prime \prime}-\mathrm{W} 53^{\circ} 45^{\prime} 15^{\prime \prime}$ & Marreco/residence, mechanical industries \\
4 & $\mathrm{~S} 24^{\circ} 42^{\prime} 11^{\prime \prime}-\mathrm{W} 53^{\circ} 42^{\prime} 30^{\prime \prime}$ & Barro Preto/horticulture and mechanical industries \\
5 & $\mathrm{~S} 24^{\circ} 45^{\prime} 11^{\prime \prime}-\mathrm{W} 53^{\circ} 45^{\prime} 07^{\prime \prime}$ & Toledo/residence, commercial area and industries \\
\hline
\end{tabular}

The collector was built with polymethyl methacrylate (acrylic) and nylon piston toned and adapted from the US model-BMH-53, which is a product of the type "piston-core" for manual use in low depths. Each sample was composed of the river center collections, as well as the left and right banks of the river. This way, amounted to approximately $1 \mathrm{~kg}$ of sediment, which were wrapped directly in polyethylene reinforced plastic bags (APHA, 2005).

In the laboratory, after removing coarse material of the sediment, these were dried and quartered. Monthly were reserved part of samples for granulometric and mineralogical analyses. Also monthly it was prepared in agate mortar and sieved in teflon meshes $(<63 \mu \mathrm{m})$ approximately $10 \mathrm{~g}$ of fine sediment for determination of trace elements and organic matter.

The extraction of total levels of trace elements was obtained by acid attack, with digestion in microwave oven, CEM brand and model MDS 2000, according to the methodology SW-846 3051A of the Environmental Protection Agency (USEPA, 2007). The aim was to obtain a pseudo total decomposition of sediments, which is more indicated for studies of contamination and environmental pollution.

The concentrations of the elements of interest was obtained according to the methodology of the Standard Methods for the examination of Water and Wastewater (APHA, 2005). It is performed by optical emission spectrometry with inductively coupled plasma (ICP-OES) using optimal model ICP 8000 equipment of Perkin Elmer. The precision and accuracy of the methods were obtained by means of a certified reference material of United Geological Survey - SGR - 1b (Green River Shale).The analyzes of the organic carbon content by dry combustion were performed on Shimadzu - TOC equipment ( $V_{\mathrm{CPH}}$ model).

It was used a descriptive statistical analysis for expressing the levels of trace elements and of macro elements. The pollution index was calculated, which allows classifying the enrichment of sediments in seven extracts of progressive intensities of contamination. To assess the intensity of metal contamination, the pollution index (Karbassi et al., 2008) was calculated using:

$$
\mathrm{I}_{\mathrm{P}}=\log _{2}\left(\frac{\mathrm{C}_{\mathrm{N}}}{\mathrm{B}_{\mathrm{N}}}\right)
$$

Where:

$C_{N}=$ concentration of the element $N$ in the fraction of silt/clay $<0,63 \mu \mathrm{m}$ of the sediment to be classified; 
$\mathrm{B}_{\mathrm{N}}=$ medium concentration of local background defined by Juchen et al., (2014);

The enrichment factor of sediment (EF) was calculated for each of the elements using the equation of standardization Eq. 2 suggested by Yongming et al., (2006). It is used aluminum as the normalizer element, by the fact that the place of study does not indicate anthropic contamination by this element.

$$
\mathrm{EF}=\frac{\left[\mathrm{E}_{\text {sample }}\right] \div\left[\mathrm{Al}_{\text {sample }}\right]}{\left[\mathrm{E}_{\text {background }}\right] \div\left[\mathrm{Al}_{\text {background }}\right]}
$$

Where:

$\mathrm{EF}=$ Enrichment Factor

$\left[E_{\text {sample }}\right]=$ Element concentration in the sample assessed;

$\left[\mathrm{Al}_{\text {sample }}\right]=$ concentration of $\mathrm{Al}$ in the sample;

$\left[E_{\text {background }}\right]=$ Average concentration of background of the element;

$\left[\left.\mathrm{A}\right|_{\text {background }}\right]=$ Average concentration of background of Al.

\section{Results and Discussion}

The results of the concentrations of the analyzed elements in sediments were obtained in dry basis, since they were taken the same procedures for soils, according with the methodology of fine ground air-dry. The results shown in Table 2 represent the efficiency of the analytical method, using as reference material standard of sediments from the sample of Green River Shale, SGR-1b of USGS (United States Geological Survey).

Table 2. Values obtained in mg. $\mathrm{kg}^{-1}$ from sample of reference Green River Shale (SGR-1b) of USGS

\begin{tabular}{|c|c|c|c|c|c|c|}
\hline \multicolumn{2}{|l|}{ Element } & \multicolumn{2}{|c|}{ Standard certificate } & \multicolumn{3}{|c|}{ ICP -OES } \\
\hline$(n=3)$ & $\begin{array}{c}\text { Blank } \\
\left(\mathrm{mg} \mathrm{kg}^{1-}\right)\end{array}$ & $\begin{array}{c}\text { Average } \pm \text { SD } \\
\left(\mathrm{mg} \mathrm{kg}^{1-}\right)\end{array}$ & $\begin{array}{l}\text { RSE } \\
\text { (\%) }\end{array}$ & $\begin{array}{l}\text { Average } \pm \text { SD } \\
\left(\mathrm{mg} \mathrm{kg}^{1-}\right)\end{array}$ & $\begin{array}{l}\text { RSE } \\
\text { (\%) }\end{array}$ & $\begin{array}{l}R \\
\text { (\%) }\end{array}$ \\
\hline $\mathrm{Ba}$ & 0.003 & $290 \pm 40$ & 13.79 & $221.22 \pm 15.66$ & 7.08 & 76.28 \\
\hline $\mathrm{Cu}$ & 0.013 & $66 \pm 9$ & 13.63 & $64.15 \pm 2.34$ & 3.66 & 97.19 \\
\hline $\mathrm{Cd}$ & 0.008 & 0.9 & - & $0.37 \pm 0.021$ & 5.67 & 41.11 \\
\hline $\mathrm{Cr}$ & 0.016 & $30 \pm 3$ & 10.00 & $26.26 \pm 1.01$ & 3.85 & 87.75 \\
\hline $\mathrm{Mn}$ & 0.003 & $267 \pm 34$ & 12.73 & $209.88 \pm 9.53$ & 4.54 & 78.61 \\
\hline $\mathrm{Ni}$ & 0.005 & 29 & - & $21.63 \pm 1.38$ & 6.74 & 74.59 \\
\hline $\mathrm{Pb}$ & 0.017 & $38 \pm 4$ & 10.52 & $33.72 \pm 3.25$ & 9.63 & 88.74 \\
\hline $\mathrm{Zn}$ & 0.048 & $74 \pm 9$ & 12.16 & $61.75 \pm 5.27$ & 8.54 & 83.45 \\
\hline
\end{tabular}

Note: n: replications; SD: standard deviation; RSE: Relative Standard Error R: recovery index

The average results and their respective deviations (efficiency of extraction) of the reference standard were obtained in aqueous matrices until the lower limit of quantification. The precision obtained through the RSE ranged from $3.85 \%$ to $\mathrm{Cr}$ and $9.63 \%$ to $\mathrm{Pb}$, data considered satisfactory for the quality control of the analytical processes. Thus, no parameter analyzed that presented RSE values greater than $10 \%$ for the reference standard was considered in this work. In addition, it was observed that the variability determined is less than the values presented by USGS for its certified values.

The Table 3 shows the results of the descriptive statistical analysis of 2,160 data obtained by monthly analyzes carried out during the annual hydrological cycle 2013/2014. These data allows a general observation and specific aspects of the anthropic contributions or natural that have been adsorbed by sediment of city rivers.

The trace elements As, Se and $U$ are not listed in Table 3 for presenting average concentrations of 0.004 , 0.005 and $0.01 \mathrm{mg} \cdot \mathrm{kg}^{-1}$ respectively and thus do not present any risk impactful to the environment 
(MINEROPAR; 2005). The high presence of Fe and Al is due to the large presence of soil LVef incorporated to sediment, however they are in lower concentrations to the background of the river bay.

Using the data of Table 3 it is possible to express the results of enrichment of sediments for heavy metals in the following proportions percentage points in relation to the background: $\mathrm{Ba}(39.3 \%), \mathrm{Cu}(44.3 \%), \mathrm{Cr}$ (56.3\%), $\mathrm{Ni}(18.6 \%), \mathrm{Zn}(140.2 \%), \mathrm{Mg}(18.4 \%)$ and $\mathrm{Na}$ (295\%). Specifically the river 5 presents the greatest percentage of enrichment, since it runs the entire central and industrial region. Thus it receives the sediment that due their mobility are delivered from the highest points to lower topographically levels of the city (Araújo \& Souza, 2012).

Table 3 The mean concentrations of trace elements and macro elements of sediments of the rivers

\begin{tabular}{|c|c|c|c|c|c|c|}
\hline Elements/River & 1 & 2 & 3 & 4 & 5 & Background \\
\hline \multicolumn{7}{|c|}{$\overline{\mathbf{x}}$} \\
\hline $\mathrm{B}\left(\mathrm{mg} \mathrm{kg}^{-1}\right)$ & 0.1 & 1.1 & 2.0 & 5.3 & 0.1 & 25.8 \\
\hline $\mathrm{Ba}\left(\mathrm{mg} \mathrm{kg}^{-1}\right)$ & 47.2 & 72.4 & 75.5 & 78.6 & 87.1 & 62.5 \\
\hline $\mathrm{Cu}\left(\mathrm{mg} \mathrm{kg}^{-1}\right)$ & 175.2 & 233.4 & 229.8 & 264.5 & 306.4 & 212.3 \\
\hline $\mathrm{Cd}\left(\mathrm{mg} \mathrm{kg}^{-1}\right)$ & 0.1 & 0.2 & 0.2 & 0.2 & 0.2 & 0.69 \\
\hline $\mathrm{Cr}\left(\mathrm{mg} \mathrm{kg}^{-1}\right)$ & 56.5 & 74.4 & 69.8 & 69.8 & 81.9 & 52.4 \\
\hline $\mathrm{Mn}\left(\mathrm{mg} \mathrm{kg}^{-1}\right)$ & 562.5 & 559.4 & 609.6 & 689.7 & 568.7 & 916.4 \\
\hline $\mathrm{Ni}\left(\mathrm{mg} \mathrm{kg}^{-1}\right)$ & 27.9 & 32.1 & 31.4 & 29.5 & 35.9 & 30.3 \\
\hline $\mathrm{Pb}\left(\mathrm{mg} \mathrm{kg}^{-1}\right)$ & 6.0 & 12.3 & 16.6 & 15.7 & 15.4 & 17.5 \\
\hline $\mathrm{Sb}\left(\mathrm{mg} \mathrm{kg}^{-1}\right)$ & 2.9 & 2.8 & 2.9 & 2.0 & 2.0 & 4.6 \\
\hline $\mathrm{Zn}\left(\mathrm{mg} \mathrm{kg}^{-1}\right)$ & 118.5 & 197.3 & 145.9 & 136.1 & 163.9 & 82.1 \\
\hline $\mathrm{Al} \%$ & 4.8 & 3.3 & 4.5 & 5.5 & 4.6 & 10.2 \\
\hline $\mathrm{Fe} \%$ & 5.4 & 7.2 & 8.6 & 8.4 & 8.5 & 10.6 \\
\hline Mg\% & 0.25 & 0.27 & .25 & 0.26 & 0.26 & 0.23 \\
\hline $\mathrm{Na} \%$ & 0.11 & 0.16 & 0.19 & 0.16 & 0.18 & 0.05 \\
\hline COT \% & 0.9 & 0.9 & 1.0 & 0.7 & 0.9 & n.r. \\
\hline
\end{tabular}

Note: $\bar{x}$ : average, n.r: Not reported

Due to the constant transport of pigs to the fridge industry in the central region of the city, the river 2 and also the other rivers, but at a lower level, presented levels of $\mathrm{Zn}$. This element is present in slurry of these animals that can contain up to $4.99 \mathrm{~g}^{\mathrm{kg}} \mathrm{gg}^{-1}$. In other words, $0.5 \%$ regarding to their chemical composition (Quadro et al., 2011).

It was not detected significant presence of $\mathrm{Cd}$, but high concentrations of $\mathrm{Cr}$ especially the points located in industrial regions similar to records of Froehner and Martins (2008).

The percentage of TOC presented distribution in average of $1 \%$ for all points of sampling and, similar to the values of $1.5 \%$ reported in studies of Belo et al, (2010). The amount of carbon and organic matter in sediments were determined for environments of artificial beaches composed of river sand in the Itaipu Lake PR. This lake is a point of watercourse for all the rivers of this study. The results show that these parameters depend on two main factors: deposition and decomposition.

The deposition is directly associated with organic production, however it is limited by the geomorphological aspects, such as: depth, local hydrodynamic of the diameter of particles, among others. The decomposition depends on the content of dissolved oxygen available, the presence of decomposer organisms and the nature of the inorganic material. In addition, other physical and chemical factors also have an influence on the process, including thermal stratification (physical) and chemistry; dynamics of water masses and potential of redux (Siqueira and Aprile, 2013).

In Table 4, it is presented the pollution index $\left(I_{p}\right)$ that result from the relationship between the contents of heavy metals and the background for fractions of sediment below the fraction $<0.063 \mathrm{~mm}$ material (silt/clay). The $I_{p}$ is presented in 7 classes (0-7) that indicate their classification of pollution. 
Table 4. Pollution index for the concentrations of sediments of river of Toledo city

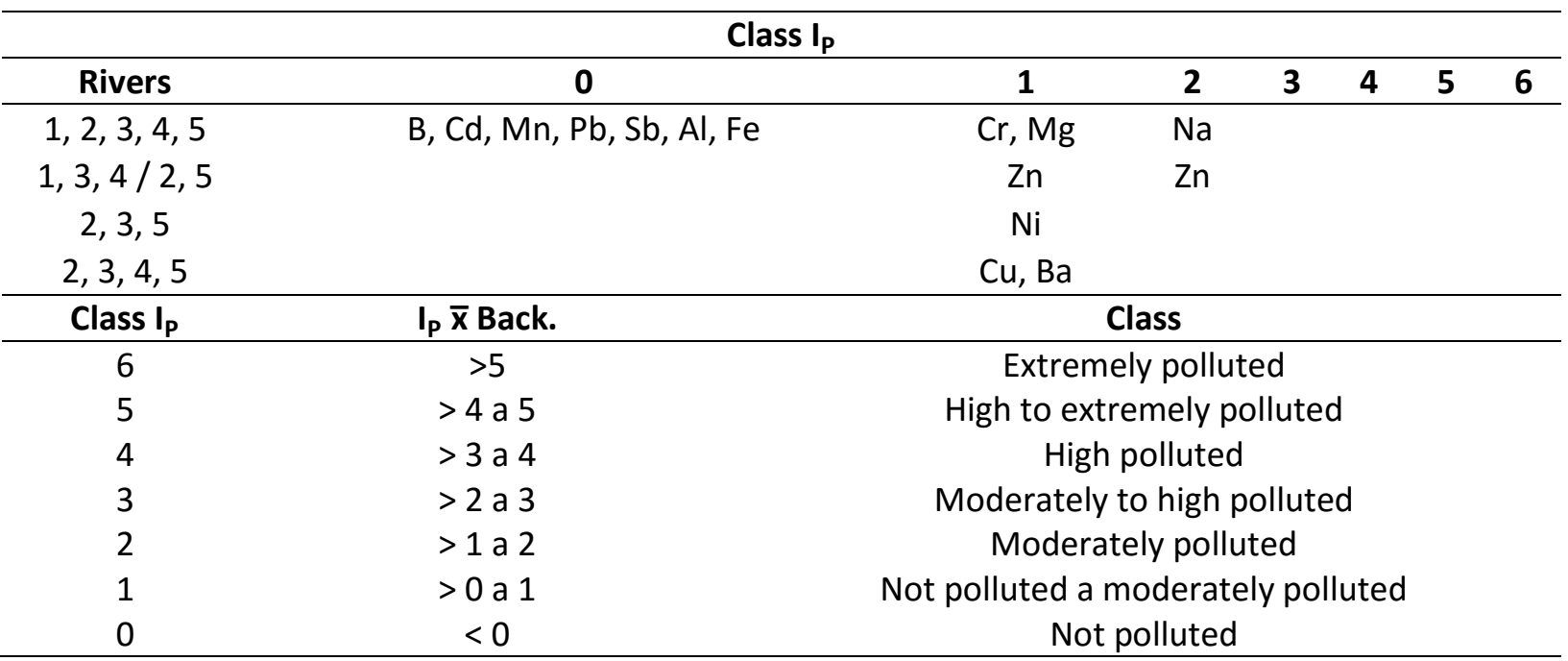

The data in Table 4 show that none of the sampling locations are classified with $I_{p}>2$, according to the classification greater than moderately polluted. The highest $I_{P}$ are due to high presence of $\mathrm{Zn}$ in all rivers and the presence of $\mathrm{Cu}, \mathrm{Ba}, \mathrm{Cr}$ and $\mathrm{Ni}$ accumulated in the sediment of rivers $2,3,5$. In relation to $\mathrm{Ba}$ and $\mathrm{Na}$, the Brazilian legislation does not make any restriction.

The $I_{p}$ determined in rivers for the levels of $Z n$ reveal the accumulation of this element that may be due to the use of agricultural fertilizers (Froehner and Martins, 2008). On the other hand, could be due effluent from pig farming present in the region, which are also rich in $\mathrm{Zn}$ (Quadro et al., 2011). The $\mathrm{Cr}$ and $\mathrm{Cu}$ are present in urban sediments due to its use in paints, fertilizers in general, algaecides, pigments, anodizing of aluminum, ceramic industries, micronutrients and tanneries (Charlesworth et al., 2003).

Table 5. Enrichment Factor of sediments of flowing bed of rivers in the urban perimeter

\begin{tabular}{|c|c|c|c|c|c|}
\hline & River 1 & River 2 & River 3 & River 4 & River 5 \\
\hline$B$ & 0.01 & 0.14 & 0.18 & 0.38 & 0.01 \\
\hline $\mathrm{Ba}$ & 1.61 & 3.65 & 2.71 & 2.33 & 3.08 \\
\hline $\mathrm{Cu}$ & 1.76 & 3.46 & 2.43 & 2.31 & 3.19 \\
\hline $\mathrm{Cd}$ & 0.42 & 0.75 & 0.74 & 0.45 & 0.58 \\
\hline $\mathrm{Cr}$ & 2.22 & 4.32 & 2.89 & 2.39 & 3.34 \\
\hline $\mathrm{Mn}$ & 1.31 & 1.92 & 1.49 & 1.40 & 1.37 \\
\hline $\mathrm{Ni}$ & 1.96 & 3.34 & 2.33 & 1.81 & 2.62 \\
\hline $\mathrm{Pb}$ & 0.73 & 2.21 & 2.14 & 1.66 & 1.94 \\
\hline $\mathrm{Sb}$ & 1.35 & 1.89 & 1.44 & 0.83 & 0.94 \\
\hline $\mathrm{Zn}$ & 3.07 & 7.56 & 3.99 & 3.07 & 4.41 \\
\hline $\mathrm{Fe}$ & 1.09 & 2.13 & 1.82 & 1.47 & 1.78 \\
\hline $\mathrm{Mg}$ & 2.30 & 3.73 & 2.47 & 2.11 & 2.48 \\
\hline $\mathrm{Na}$ & 4.61 & 10.31 & 8.87 & 5.88 & 8.03 \\
\hline \multicolumn{6}{|c|}{ Classification of the enrichment factor - EF (Yongming et al., 2006) } \\
\hline \multicolumn{3}{|c|}{ Class } & \multicolumn{3}{|c|}{ Sediment Quality } \\
\hline \multicolumn{3}{|c|}{$\mathrm{EF}<2$} & \multicolumn{3}{|c|}{ Very low enrichment } \\
\hline \multicolumn{3}{|c|}{$E F=2-5$} & \multicolumn{3}{|c|}{ Moderate enrichment } \\
\hline \multicolumn{3}{|c|}{$E F=5-20$} & \multicolumn{3}{|c|}{ Significant enrichment } \\
\hline \multicolumn{3}{|c|}{$E F=20-40$} & \multicolumn{3}{|c|}{ Very high enrichment } \\
\hline \multicolumn{3}{|c|}{$\mathrm{EF}>40$} & \multicolumn{3}{|c|}{ Extremely high enrichment } \\
\hline
\end{tabular}

Note:* written in bold values $\mathrm{EF}>2$.

The trace elements As, Se and $U$ are not listed in Table 3 for presenting average concentrations of 0.004 , 0.005 and $0.01 \mathrm{mg} \cdot \mathrm{kg}^{-1}$ respectively and thus do not present any risk impactful to the environment (MINEROPAR, 2005). The high presence of $\mathrm{Fe}$ and $\mathrm{Al}$ is due to the large presence of soil LVef incorporated to sediment, however they are in lower concentrations to the background of the river bay. 
Using the data of Table 3 it is possible to express the results of enrichment of sediments for heavy metals in the following proportions percentage points in relation to the background: $\mathrm{Ba}(39.3 \%), \mathrm{Cu}(44.3 \%), \mathrm{Cr}$ (56.3\%), Ni (18.6\%), Zn (140.2\%), Mg (18.4\%) and $\mathrm{Na}(295 \%)$. Specifically the river 5 presents the greatest percentage of enrichment, since it runs the entire central and industrial region. Thus, it receives the sediment that due their mobility are delivered from the highest points to lower topographically levels of the city (Araújo and Souza, 2012).

The EF was moderate to significant for approximately half of the elements analyzed and distributed by all the rivers sampled. According to the classification of Yongming et al., (2006), the values in bold presented in Table 5 for elements $\mathrm{Ba}, \mathrm{Cu}, \mathrm{Cr}, \mathrm{Ni}, \mathrm{Pb}$ and $\mathrm{Zn}$ become hazardous under the point of view of potential polluter to water of these rivers. Since this enrichment is an accumulation of heavy metals that may pollute the water of these rivers forward to any environmental variation. It is observed that the oxides of Fe and $\mathrm{Mn}$ despite of do not presenting EF expressive, may be responsible for specific adsorption of certain metals. Especially for $\mathrm{Cr}, \mathrm{Cu}$ and $\mathrm{Pb}$ by forming strong complexes of internal ball (specific adsorption) with these minerals and occlusion in carbonates (Mcbride and Spiers, 2001).

The results of pollution index and enrichment factor show that urban sediments are characterized by significant presence of $\mathrm{Zn}, \mathrm{Cr}$ and $\mathrm{Cu}$. Thus, indicate that the sediments are enriched in urban drainage bay by these elements. Then they are accumulated in beds of the flowing rivers mainly by rainwater where can cause over time its dispersion in the aquatic environment by various mechanisms physical, chemical and biological.

This study also uses guidelines of the agencies of environmental protection of Spain, Netherlands, United States (EPA) and Canada (Table 6), due its parameters allow the evaluation of anthropic conditions of this river bay.

Table 6. Permissible values in $\mathrm{mg} . \mathrm{kg}^{-1}$ of trace elements by environmental protection agencies in Spain, Netherlands, United States (EPA) and Canada

\begin{tabular}{cccccccccccc}
\hline & \multicolumn{2}{c}{ Spain } & \multicolumn{1}{c}{ Holland } & \multicolumn{2}{c}{ EUA } & \multicolumn{2}{c}{ Canada } \\
\hline & AL & AL2 & TV & AV & ERL & ERM & TEL & PEL & LM & River & Back* \\
\hline $\mathbf{C d}$ & 1 & 5 & 0.8 & 12 & 1.2 & 9.6 & 0.68 & 4.21 & 0.26 & $2,3,4,5$ & 0.69 \\
\hline $\mathbf{C r}$ & 200 & 1000 & 100 & 380 & 81 & 370 & 52 & 160 & 81.9 & 5 & 54.2 \\
\hline $\mathbf{C u}$ & 100 & 400 & 35 & 190 & 34 & 270 & 19 & 108 & 306.4 & 5 & 212.3 \\
\hline $\mathbf{N i}$ & 100 & 400 & 35 & 210 & 20.9 & 51.6 & 15.9 & 42.8 & 35.9 & 5 & 30.26 \\
\hline $\mathbf{P b}$ & 120 & 600 & 85 & 530 & 46.7 & 218 & 30.2 & 112.2 & 15.7 & 4 & 17.6 \\
\hline $\mathbf{Z n}$ & 500 & 3000 & 140 & 720 & 150 & 410 & 124 & 271 & 197.3 & 2 & 82.14 \\
\hline
\end{tabular}

Spain - < AL1(action limit): value below which allows disposal of dredged material; between AL1 and AL2:

moderate contamination, the material require additional study before its disposal may be permitted; $>$ AL2: dredged material must be isolated;

Holanda - < TV (target value): not polluted; between TV and AV (action value): slightly polluted to polluted; > AV heavily polluted;

EUA - ERL (effects range-low): value below which biological effects are rare; ERM (effects range-median): value above which are expected frequent biological effects;

Canadá - TEL (threshold effects level): value from which can be expected adverse effects; PEL (probable effects level): values above which adverse effects are often expected.

Fonte: LM: limit maximun, *background, Juchen et al., (2014); DelValls et al., (2004).

The maximum content of $0.26 \mathrm{mg} \cdot \mathrm{kg}^{-1}$ detected for the $\mathrm{Cd}$ are for all guidelines considered in this study a sediment not polluted. The content of $\mathrm{Cr}$ that has reached maximum value of $81.9 \mathrm{mg} \cdot \mathrm{kg}^{-1}$ in Rio 5 are for the Canadian guide a level from which can be expected adverse effects to the environment.

The Cu surpasses all parameters allowed for all heavy metals in sediments for guidelines of Spanish, Dutch, American and Canadian and must be analyzed from two points of view. First, by expressive content of its background of $212.3 \mathrm{mg} \cdot \mathrm{kg}^{-1}$.

Second, by the accumulated content of $306.4 \mathrm{mg} \cdot \mathrm{kg}^{-1}$ checked in river 5 . This amount is due to the waste of pigs which contains up to $193 \mathrm{mg} \cdot \mathrm{kg}^{-1}$ of Copper (Quadro et al., 2011) and which are released daily in 
the rivers of this city. These authors also say that these $\mathrm{Zn}$ residues reach $2300 \mathrm{mg} \cdot \mathrm{kg}^{-1}$ what explains the levels of $197.3 \mathrm{mg} \cdot \mathrm{kg}^{-1}$ checked in river 2 . This is consequences from the agro industrial activity represented by 455 thousand pigs that occupies the 3rd position between the Brazilian producers (IBGE, 2011).

The maximum value of $35.9 \mathrm{mg} \cdot \mathrm{kg}^{-1}$ of $\mathrm{Ni}$ in river 5 , according to the legislation Environmental Protection Agency (EPA), would be a sediment that has value above which the biological effects are rare. For the Canadian legislation are levels above which can be expected adverse effects in the environment. However, this study shows that the levels of $\mathrm{Cu}$ and $\mathrm{Ni}$ are relatively close to the levels determined by the background, thus only consider the permissible values by the guidelines would be ineffective in this evaluation.

The $\mathrm{Pb}$ reached maximum concentration of $15.7 \mathrm{mg} \cdot \mathrm{kg}^{-1}$ and below the limits imposed by the guidelines and the background. The levels of $\mathrm{Zn}$ show that the sediments are classified as slightly polluted to polluted, according to Dutch guideline, and are close to the values above of which are expected biological effects frequent according to the Canadian and American guidelines. Lastly, when analyzing the levels of heavy metals concentrated in sediments of flowing urban rivers, this study allows a different evaluation of potential polluter of sediments for the aquatic environment. Therefore, becomes a relevant scientific basis for studies of water quality of urban rivers.

\section{Conclusions}

The enrichment of sediments occurred mainly by heavy metals of $\mathrm{Zn}, \mathrm{Cr}$ and $\mathrm{Cu}$, resulting from activities characteristic of this city. The river 5 , which runs through the entire urban perimeter, presented larger loads of these elements. The other rivers analyzed showed strong characteristics of anthropic contributions. Their sediments featured contamination by heavy metals from Toledo city-PR. Compared with the levels of local background, the sediments of the rivers were enriched by trace elements in the following percentage proportions: $\mathrm{Ba} 39.3 \%$, Cu 44.3\%, Cr 56.3\%, , Ni 18.6\%, Zn 140.2\%, Mg 18.4\% and $\mathrm{Na} 295 \%$. The percentage of TOC in sediments presented average distribution of $1 \%$ in all sampling sites analyzed. The highest pollution index obtained by sediments classifies them as moderate to heavily polluted. $\mathrm{Zn}$ and $\mathrm{Na}$ are the main elements responsible for this index. The enrichment factor was considered moderate to significant for the majority of sediments of their respective rivers. According to the principal guidelines, the contents of $\mathrm{Cd}, \mathrm{Cu}$ and $\mathrm{Zn}$ overcome some of the limits allowed for these elements in sediments. However this study shows that the levels of $\mathrm{Cu}$ and $\mathrm{Ni}$ are relatively close to the levels determined by the background, thus only consider the permissible values by the guidelines would be an ineffective evaluation. Finally, this study allows a different way to assess the potential polluter of rivers by the perspective of analysis of its sediments, becoming a relevant scientific tool for studies of water quality of urban rivers.

\section{References}

APHA - American Public Health Association; AWWA - American Water Works Association \& Wef (2005). Water Environment Federation. Standard Methods for the Examination of Water and Wastewater. Washington D.C: Ed Greenberg, p. 20.

Araújo B.F., Almeida M.G., Salomão M.S.M.B., Gobo R.R., Siqueira V.C. Ovalle A.R.C. and Rezende C.E. (2010), Total $\mathrm{Hg}$ distribution and their association with different geochemical brackets in marine sediments of the Brazilian continental margin: Campos Basin - Rio de Janeiro, Quím. Nova, 33, 501-507.

Araújo J.A., Souza R.F. (2012), Anthropogenic contribution of heavy metals in sediments of landfill areas, current agricultural and urbanised in Parelhas-RN, Brazil's semi-arid region, Rev. Geog., 21, 5-22.

Beltrán R., Rosa J.D., Santos J.C., Beltrán M. and Gómez Ariza J.L. (2010), Heavy metal mobility assessment in sediments from the Odiel River (Iberian Pyritic Belt) using sequential extraction, Environ. Earth Sci., 61, 1493-1503. 
Belo A., Quinaia S.P. and Pletsch A.L. (2010), Evaluation of contamination of metals in surface sediments from the beaches of the Itaipu Lake, Quím Nova, 33(3), 613-617.

BRAZIL Resolution n. 344 of 25 March 2004. Ministry of Environment. CONAMA - National Council for the Environment. Available at: http://www.mma.gov.br. (Accessed Dec. 2014).

Cardoso A.R. and Poleto C. (2012), Concentrations of zinc and nickel in sediments from Urban Thirty municipalities in Rio Grande do Sul: risks to State water resources, Rev. Bras. Recursos Hídricos, 17(3), 93-100.

Charlesworth S.M., Everett M., Mcarthy R., Ordoñez A. and De Miguel E. (2003), A comparative study of heavy metal concentration and distribution in deposited street dusts in a large and a small urban area: Birmingham and Coventry, West Midlands, UK, Environ. Int., 29, 563 -573.

Delvalls T.A., Andres A., Belzunce M.J., Buceta J.L., Casado-Martinez M.C., Castro R., Riba I., Viguri J.R. and Blascoet J. (2004), Chemical and ecotoxicological guidelines for managing disposal of dredged material, Trends in Anal. Chem., 23(10-11), 819-828.

EMBRAPA - Brazilian Agricultural Research Corporation (2013). Brazilian system of soil Classification. Brasília, DF. $353 \mathrm{p}$.

Feng J.L., Wang G.L., Sun J.H., Sun S.P. and Liu X.F. (2010), Metals in water and surface sediments from Henan reaches of the Yellow River, China, Sci. China Chem., 53, 1217-1224.

Froehner S. and Martins R. (2008), Evaluation of chemical composition of sediments Barigui River in Curitiba metropolitan region, Quím. Nova, 31(8), 2020-2026.

Grosbois C.A., Horowitz A.J., Smith J.J. and Elrick K.A. (2001), The effect of mining and related activities on the sediment-trace element geochemistry of Lake Coeur d'Alene, Idaho, USA. Part III. Downstream effects: The Spokane River Basin, Hydrol. Process, 15, 855-875.

Hejabi A.T., Basavarajappa H.T., Karbassi A.R. and Monavari S.M. (2011), Heavy metal pollution in water and sediments in the Kabini River, Karnataka, India, Environ. Monit. Assess., 182, 1-13.

IBGE - The Brazilian Institute of Geography and Statistics (2011). Synopsis of the demographic census 2010. Available at: http://www.ibge.gov.br. (Accessed abr. 2014).

IBGE - The Brazilian Institute of Geography and Statistics (2011). Livestock Production. Rio de Janeiro, 39, 1-63.

Juchen C.R., Vilas Boas M.A., Poleto C. and Macedo M. (2014), Geochemical background for watershed managing obtained in eutroferric red latosol, J. Food Agric. Environ., 12, 766-769.

Kabata-Pendias A. and Mukherjee A.B. (2007), Trace elements from soil to human. New York: Springer, 450 p.

Karbassi A.R., Monavari S.M., Nabi Bidhendi Gh.R., Nouri J. and Nematpour K. (2008), Metal pollution assessment of sediment and water in the Shur River, Environ. Monit. Assess., 14(7), 107-116.

Mcbride M.B. and Spiers G. (2001),Trace elements content of selected fertilizers and dairy manures as determined by ICP-MS, Commun. Soil Sci. Plant Anal., 32, 139-156.

MINEROPAR MINERAIS DO PARANÁ S. A. (2005) Multielementary Geochemical Survey of the State of Paraná, geochemistry of soil Horizon B: Final project report, v.1, 411 p.

Quadro M., Castilhos D., Castilhos R. and Vivian G. (2011), Biomass and microbial activity in soil plus pig waste, Rev. Bras. Agrociência, 17, 85-93.

Siqueira G.W. and Aprile F. (2013), Environmental risk assessment for metallic contamination and organic material in Aurá River basin sediment, the metropolitan region of Belém - PA, Acta Amazônia, 43, 51-61.

SEDNET - European Sediment Research Network. Available at: http://www.sednet.org. (Accessed Nov. 2012).

USEPA - United States Environmental Protection Agency. Microwave assisted acid digestion of sediments sludge, soils, and oils, EPA SW 846 3051a, 30p, 2007. Available at: http://www.epa.gov/epawaste/hazard/testmethods. (Accessed Feb. 2013).

Wang S.L., Lin C. and Cao X.Z. (2011), Heavy metals content and distribution in the surface sediments of the Guangzhou section of the Pearl River, Southern China, Environ. Earth Sci., 64, 1593-1605.

Yongming B.D.H., Peixuana T.D., Junjib C. and Posmentierc E.S. (2006), Multivariate analysis of heavy metal contamination in urban dusts of Xi'an, Central China, Sci. Total Environ., 355, 176-186. 